\title{
FAKTOR DETERMINAN KOMPLIKASI DAN RUJUKAN KASUS OBSTETRI
}

\author{
Nasrudin Andi Mappaware \\ Bagian OBGIN Fakultas Kedokteran UMI
}

\section{PENDAHULUAN}

\section{Latar Belakang}

Jaminan Kesehatan Nasional (JKN) merupakan implementasi dari UU Nomor 40 Tahun 2004 tentang Sistem Jaminan Sosial Nasional (SJSN) di bidang kesehatan dengan konsep Universal Health Coverage (UHC) yang memaksa pesertanya mengikuti sistem rujukan untuk mendapatkan pelayanan kesehatan komprehensif, murah, terjangkau, namun berkualitas ${ }^{(1)}$. Diberlakukannya SJSN ini jelas menuntut dilakukannya peningkatan akses dan mutu pelayanan kesehatan, baik pada fasilitas kesehatan tingkat pertama maupun fasilitas kesehatan tingkat lanjutan, serta perbaikan sistem rujukan pelayanan kesehatan.Pelayanan yang proaktif itu adalah "Sistem Rujukan Nasional".

Pada Pasal 5 PMKNo. 001 Tahun 2012, dinyatakan bahwa sistem rujukan diwajibkan bagi peserta jaminan kesehatan atau asuransi kesehatan sosial dan juga pemberi pelayanan kesehatan. Dengan Sistim Rujukan Nasional ini dapat mengenal kelompok Golongan Risiko Tinggi yang memerlukan penanganan khusus yang tidak terdapat di layanan kesehatan primer seperti Puskesmas. ${ }^{(2)}$ Rujukan pelayanan kesehatan dimulai dari pelayanan kesehatan primer dan diteruskan ke jenjang pelayanan sekunder dan tersier yang hanya dapat diberikanjika ada rujukan dari pelayanan primer atau sekunder, minimal di Rumah Sakit Kota. ${ }^{(2)}$

Diketahui bahwa dari 86\% sistim rujukan bermasalah dalam mencapai akses pelayanan kesehatan $40,5 \%$ yang bermasalah denganjarakyangberdampakpadakomplikasi obstetrik. Kendala dalam pelaksanaan rujukan mempengaruhi kematian maternal dan perinatal. Ada tiga "terlambat" yang mempengaruhi kematian maternal/perinatal adalah terlambat mengenali bahaya dan mengambil keputusan merujuk, terlambat mencapai fasilitas kesehatan rujukan dan terlambat memperoleh pelayanan adekuat di fasilitas rujukan. ${ }^{(1,2)}$

Angka Kematian Ibu (AKI) merupakan salah satu indikator untuk melihat derajat kesehatan perempuan- AKI juga merupakan salah satu target yang telah ditentukan dalam Millennium Development Goals (MDGs), yaitu meningkatkan kesehatan ibu di mana target yang akan dicapai sampai tahun 2015 adalah mengurangi sampai 3/4 risiko jumlah kematian ibu. Berdasarkan Survey Demografi dan Kesehatan Indonesia (SDK1) terakhir tahun 2007 AKI Indonesia menurun menjadi 228 per 100.000 kelahiran hidup, meskipun demikian angka tersebut masih tertinggi di Asia. Sedangkan Angka Kematian Bayi (AKB) di Indonesia, diperoleh estimasi sebesar 34 per 1000 kelahiran hidup. Sedangkan menurut MDG's 
2015 angka kematian ibu diharapkan 102/100.000 kelahiran hidup. Angka kematian perinatal 32/1000 kelahiran hidup, sementara target angka kematian bayi yang diharapkan 23/1000 kelahiran hidup. $^{(2,3)}$

AKI dan AKB yang sangat tinggi di Indonesia ini diakibatkan oleh adanya komplikasi-komplikasi dalam persalinan. Data Kementerian Kesehatan menunjukkan angka kematian bayi dan ibu saat melahirkan mengalami penurunan sejak 2015 hingga semester pertama 2017. Berdasarkan data yang dikutip dari Kementerian Kesehatan, jumlah kasus kematian bayi turun dari 33.278 kasus pada 2015 menjadi 32.007 kasus pada 2016. Pada pertengahan tahun atau semester satu 2017 tercatat sebanyak 10.294 kasus kematian bayi. Demikian pula dengan angka kematian ibu saat melahirkan turun dari 4.999 kasus pada 2015 menjadi 4.912 kasus di tahun 2016. Sementara hingga semester satu di tahun 2017 terjadi 1.712 kasus kematian ibu saat proses persalinan.

Pencapaian indikator angka kematian bayi di Kota Makassar telah melampaui target yang telah ditetapkan, dari yang ditargetkan 7/1000 Kelahiran Hidup (KH) di tahun 2015 ternyata menunjukkan pencapaian yang baik dengan lebih rendahnya Angka Kematian Bayi yaitu 1,79/1000 KH (45 kematian bayidari 25.181 kelahiran hidup). Angka kematian bayi juga menurun dari tahun-tahun sebelumnya yaitu 2,60/1000 KH (64 kematian bayidari 24.590 kelahiran hidup) tahun 2014 dan 6,71/1000 KH (165 kematian dari sebanyak 24.576 kelahiran hidup) di tahun 2013.

Di Kota Makassar, AKI maternal mengalami fluktuasi selama 3 tahun terakhir yaitu pada tahun 2015 sebanyak 5 kematian ibu dari 25.181 kelahiran hidup (AKI: 19,86/100.000 KH). Jumlah kematian ibu tahun 2014 sama dengan tahun 2015 yaitu 5 kematian ibu tapi berbeda pada kelahiran hidup yaitu 24.590 (AKI: 20,33/100.000 KH). Tahun 2013 terdapat 4 kematian ibu dari 24.576 kelahiran hidup (AKI: $16,28 / 100.000 \mathrm{KH}$ ). Upaya yang dilakukan dalam mengantisipasi masalah kematian ibu yaitu melalui peningkatan peran kader Posyandu agar proaktif mendampingi ibuibu hamil dalam mendapatkan pelayanan kesehatan (K1-K4) serta penyuluhanpenyuluhan sehingga diharapkan ibu-ibu hamil sadar akan kondisi kesehatannya dan mengutamakan pertolongan persalinan dari Tenaga Kesehatan yang berkompeten (Dokter dan Bidan).

Angka kematian ibu di Kota Makassar menunjukkan penurunan dari 20,33/100.000 KH di Tahun 2014 menjadi 19,85/100.000 KH ditahun 2015, dimana terjadi 5 kematian ibu dari sejumlah 25.181 kelahiran hidup di Kota Makassar. Terdapat 3 penyebab kematian ibu di Kota Makassar diantaranya 2 kasus disebabkan perdarahan, preeklampsi dan preeklampsi berat dan edema.

Ada perbedaan yang cukup nyata antara angka kematian maternal di kawasan Timur Indonesia (KTI) yaitu $2 \%$ sedangkan diJawaBali hanya 0,7\%. Halini mencerminkan adanya perbedaan pola kematiandalamsegi geografis, akses, dan kualitas pelayanan kesehatan serta sumber daya manusia. Komplikasi obstetrik sangat berpengaruh terhadap sistem rujukan dan beberapa faktor determinan psikososial dan mediko obstetrik. Ini merupakan masalah kompleks karena menyangkut banyak hal, yakni derajat kesehatan termasuk status 
kesehatan reproduksi dan status gizi ibu sebelum dan selama kehamilan. Kejadian komplikasi obstetrik terdapat pada sekitar $20 \%$ dari seluruh ibu hamil, namun kasus komplikasi obstetrik yang ditetapkan untuk awal tahun 2012 sampai akhir tahun 2016 adalah minimal $12 \%$ dari semua ibu hamil (atau 60 \% dari kasus komplikasi obstetrik). Peningkatan kasus komplikasi diatas ini disebabkan oleh faktor determinan psikososial dan medikoobstetrik. Faktor determinan psikososial seperti umur, pendapatan, motivasi, pendidikan, pekerjaan dan kepercayaan. Faktor determinan Medikoobstetrik seperti Paritas, usia kehamilan, Riwayat ANC, Riwayat persalinan buruk, komplikasi obstetrik dan Tipe rujukan fasilitas.

Di Kota Makassar terdapat satu rumah sakit umum pusat yaitu RSUP Dr. Wahidin Sudirohusodo (RSWS) dengan status tipe rumah sakit paling tinggi (tipe A), sementara strata dibawahnya yaitu dengan jejaring RSUD lain dan RS bersalin khusus ibu dan anak (seperti RSKDIA Pertiwi, RSKDIA St. Fatimah dan RSIASt. Khadijah 1) yang dikelola pemerintah provinsi, pemerintah daerah dan swasta, khususnya dalam hal ini menyangkut pada kasus rujukan dengan faktor determinan psikososisal dan mediko obstetrik.

Sistem rujukan dalam bidang obstetrik pada dasarnya mempunyai maksud dan tujuan untuk memberikan pelayanan yang sesuai dengan yang diperlukan ibu hamil khususnya yang perlu dirujuk untuk mendapatkan perawatan spesialistik ditambah fasilitas yang baik, teknik operasi yang baik berlangsung lebih asepsis, teknik anestesi bertambah baik, kenyamanan pasca operasi dan lama perawatan yang menjadi lebih singkat sehingga dapat dicapai tingkat kesehatan ibu hamil, bersalin, dan nifas yang optimal. Dengan adanya sistem rujukan yang baik diharapkan kasus kasus dengan resiko tinggi dapat ditangani dengan lebih cepat, tepat, dan berkesinambungan, yang pada akhirnya kematian ibu dan anak sebagai tolak ukur pelayanan kesehatan reproduksi dapat diturunkan disamping itu morbiditas dan mortalitas maternal dan perinatal dapat diturunkan secara bermakna. ${ }^{(3)}$

Dengan melihat rangkaian permasalahan di atas maka penulis tertarik untuk meneliti penelitian ini dan diharapkan dapat memberikan sumbangan teori dan praktis terutama dalam mengembangkan suatu perspektif analitik baru dalam meningkatkan status kesehatan berdasarkan potensi psikososial dan mediko obstetrik yang didapati masyarakat. Kenyataan yang ada, kasus rujukan dapat menjadi acuan dibuatnya audit mutu rujukan dengan membandingkan antara standar mutu layanan beberapa rumah sakit di Kota Makassar. Berdasarkan sebaran kasus rujukan obstetri dan ginekologi di kota Makassar dan RS Gowa Januari- Juni 2015 pada RS Wahidin 111 kasus, RS Pertiwi 12 kasus dan RS Khadijah 1 kasus. Data tersebut belum termasuk kasus rujukan dari konsulen. Berdasarkan beberapa hal diatas maka yang menjadi permasalahan adalah bagaimanakah faktor determinan psikososial dan mediko obstetrik pasien rujukan dengan komplikasi obstetrik masih seringditemukan dalam upaya penyelamatan dan rujukan ke Rumah Sakit. Pemanfaatan rujukan primer masih rendah (underutilised) sehingga terjadi inefiseinsi rujukan padahal system rujukan pelayanan kegawatdaruratan maternal dan neonatal mengacu pada prinsip utama kecepatan dan 
ketetapan tindakan efisien, efektif dan sesuai dengan kemampuan dan kewenangann fasilitas kesehatan. Penelitian ini diharapkan dapat menyumbangkan perspektif baru serta perlu dilakukan pengkajian lebih lanjut. ${ }^{(4,5)}$

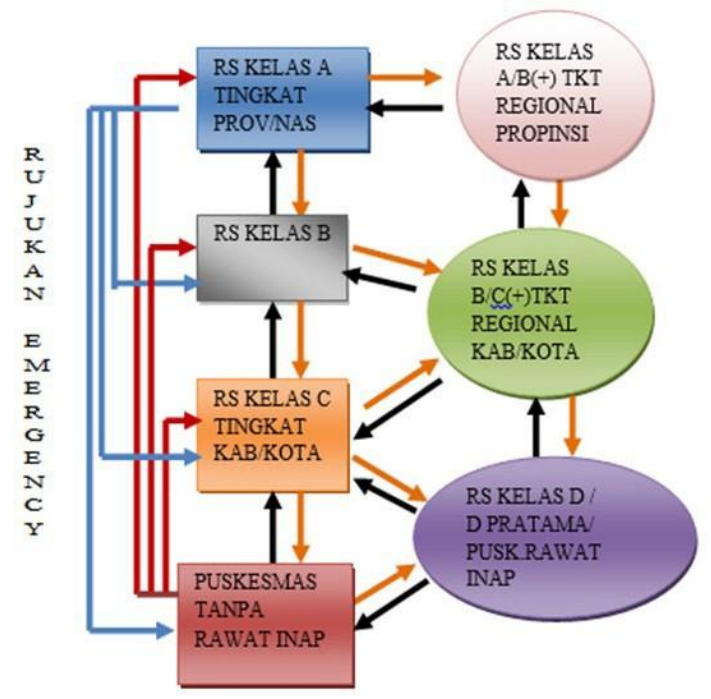

Gambar 1. Alur Sistem Rujukan Nasional Pada BanyakFasilitas Pelayanan Kesehatan

\section{PEMBAHASAN}

\section{Faktor Determinan}

Determinan Kesehatan adalah faktorfaktor yang menentukan dan mempengaruhi (membentuk) status kesehatan dari individu atau masyarakat. Menurut Bloom, 1978, yang termasuk ke dalam determinan kesehatan meliputi genetik, lingkungan, pelayanan kesehatan, dan perilaku individu. Determinan kesehatan pada obstetrik berupa psikososial, mediko-obstetrik, fasilitas kesehatan, dan tenaga kesehatan. Faktor psikososial meliputi usia ibu, suku daerah, agama/kepercayaan, tingkat pendidikan, pekerjaan, sumber biaya. Mediko obstetrik keadaan individu dari ibu selama kehamilan meliputi paritas/jumlah persalinan, jarak persalinan, dan riwayat obstetrik yang menyebabkan pertimbangan pengambilan dalam keputusan tindakan persalinan ataupunrujukan. ${ }^{(6)}$

Menurut Simon-Morton, dan Green 1995 determinan kesehatan meliputi Genetik, Lingkungan fisik, Lingkungan Sosial, Pelayanan kesehatan, dan Perilaku. Perbedaaan dengan teori Blum adalah untuk determinan lingkungan lebih dispesifikan menjadi lingkungan fisik dan lingkungan sosial.

Determinan psisosial menurut SimonMorton meliputi ekonomi, agama, gender, budaya, demografi, populasi penduduk. Status ekonomi seringkali mempengaruhi status kesehatan individu. Aksesterhadap pelayanan kesehatan yang terhambat akibat kemiskinan menjadi faktor yang mempengaruhi kesehatan seseorang. Agama menjadi determinan sosial karena agama merupakan panutan bagaimana seseorang individu berperilaku baik sebagai social maupun sebagai individu itu sendiri. Gender menjadi determinan sosial karena di beberapa Negara, termasuk Indonesia, isu gender masih sangat kental. Kaum laki laki lebih dominan daripada perempuan, termasuk dalam hal kesehatan. Budaya patriakal merupakan salah satu contoh determinan social dalam hal budaya. Menempatkan laki laki (suami) sebagai pelindung, dan pengambil keputusan untuk semuanya kadangkala sangat menentukan terhadap status kesehatan masing masing individu.

\section{Faktor Psikososial}

Psikososial adalah suatu kondisi yang terjadi pada individu yang mencakup aspek psikis dan sosial atau sebaliknya. Psikososial menunjuk pada hubungan yang dinamis antara faktor psikis dan sosial, yang saling berinteraksi dan memengaruhi satu sama lain. 
Psikososial sendiri berasal dari kata psiko dan sosial. Kata psiko mengacu pada aspek psikologis dari individu (pikiran, perasaan dan perilaku) sedangkan sosial mengacu pada hubungan eksternal individu dengan orangorang di sekitarnya (Pusat Krisis Fakultas Psikologi UI). Istilah psikososial berarti menyinggung relasi sosial yang mencakup faktor-faktor psikologis (Chaplin, 2011).

Psikososial persalinan Adalah setiap perubahan dalam kehidupan individu, baik yang bersifat psikologik maupun sosial yang mempunyai pengaruh timbal balik. Faktorfaktor determinan psikososial dalam obstetri meliputi umur, suku, agama, pekerjaan dan tempat tinggal. ${ }^{(9)}$

\section{Faktor Umur Ibu}

Umur reproduksi optimal bagi seorang ibu adalah antara 20 - 35 tahun, dibawah dan di atas umur tersebut akan meningkatkan risiko kehamilan dan persalinan. Pada usia muda organ-organ reproduksi seorang wanita belum sempurna secara keseluruhan dan perkembangan kejiwaan belum matang sehingga belum siap menjadi ibu dan menerima kehamilannya dimana hal ini dapat berakibat terjadinya komplikasi obstetri yang dapat meningkatkan angka kematian ibu dan perinatal.Umur dalam penelitian ini adalah umur responden pada saat melahirkan dan dihitung dalam tahun berdasarkan catatan pada buku laporan usia 20-35 tahun merupakan usia reproduksi wanita dimana di usia tersebut seorang ibu mampu hamil dalam kondisi yang sehat baik secara fisik maupun secara psikologis.

Kehamilan di atas umur 35 tahun mempunyai risiko 3 kali lebih besar terjadinya persalinan seksio sesarea dibandingkan dengan umur di bawah 35 tahun $^{(10)}$.

\section{Suku Daerah}

Menurut Philip Kotler, banyak faktor yang mempengaruhi perilaku seseorang, salah satunya adalah faktor sosial dan kebudayaan. Suku termasuk bagian dari budaya yang tentunya akan mempengaruhi perilaku dalam menggunakan pelayanan kesehatan termasuk pelayanan kebidanan. Suku daerah merupakan faktor penentu yang paling dasar dari keinginan dan perilaku seseorang. Bila makhluk-makhluk lainnya bertindak berdasarkan naluri, maka perilaku manusia umumnya dipelajari. Sedangkan manusia, perilakunya biasanya dipelajari dari lingkungan sekitarnya. Sehingga nilai, persepsi, preferensi, dan perilaku antar seorang yang tinggal pada daerah tertentu dapat berbeda dengan orang lain yang berada di lingkungan yang lain pula. Sehingga pemasar sangat berkepentingan untuk melihat pergeseran kultur tersebut agar dapat menyediakan produk dan jasa yang diinginkan konsumen. ${ }^{(10)}$

\section{Agama/Kepercayaan}

Agama merupakan salah satu faktor sosio demografi yang mempengaruhi penggunaan pelayanan kesehatan termasuk pelayanan kebidanan yang merupakan salah satu bentuk dari pelayanan kesehatan yang bertujuan untuk menjamin agar setiap wanita hamil dan menyusui dapat memelihara kesehatannya sesempurna mungkin, dapat melahirkan bayi yang sehat tanpa gangguan apapun dan dapat merawatnya dengan baik. Melahirkan merupakan suatu peristiwa yang dianggap sakral, sehingga dalam pelaksanaannya biasanya disesuaikan dengan ajaran agama yang dianut oleh ibu mulai dari 
awal kehamilan sampai waktu persalinan nanti. Persalinan yang dilakukan dengan seksio sesarea sering dikaitkan dengan masalah kepercayaanyangmasihberkembang di Indonesia. Masih banyak penduduk di kota-kota besar mengaitkan waktu kelahiran dengan peruntungan nasib anak dilihat dari faktor ekonomi. Tentunya tindakan seksio sesarea dilakukan dengan harapan apabila anak dilahirkan pada tanggal dan jam sekian, maka akan memperoleh rezeki dan kehidupan yang baik. ${ }^{(10)}$

\section{Tingkat Pendidikan}

Ibu dengan pendidikan lebih tinggi cenderung lebih memperhatikan kesehatannya selama kehamilan bila dibanding dengan ibu yang tingkat pendidikannya lebih rendah. Pendidikan ibu merupakan salah satu faktor penting dalam usaha menjaga kesehatan ibu, anak dan juga keluarga. Semakin tinggi pendidikan formal seorang ibu diharapkan semakin meningkat pengetahuan dan kesadarannya dalam mengantisipasi kesulitan dalam kehamilan dan persalinannya, sehingga timbul dorongan untuk melakukan pengawasan kehamilan secara berkala dan teratur. Persalinan seksio sesarea lebih sering terjadi pada ibu yang mempunyai pendidikan yang lebih rendah. ${ }^{(11)}$.

\section{Pekerjaan}

Derajat sosio ekonomi masyarakat akan menunjukkan tingkat kesejahteraan dan kesempatannya dalam menggunakan dan menerima pelayanan kesehatan. Jenis pekerjaan ibu maupun suaminya akan mencerminkan keadaan sosio ekonomi keluarga. Beberapa alasan yang mendasari kecenderungan melahirkan dengan seksio sesarea semakin meningkat terutama di kota-kota besar, seperti di Jakarta banyak para ibu yang bekerja. Mereka sangat terikat dengan waktu. Mereka sudah memiliki jadwal tertentu, misalnya kapan harus kembali bekerja. ${ }^{(11)}$

\section{Sumber Biaya}

Biaya persalinan bersumber dari pendapatan keluarga/biaya sendiri, atau ditanggung oleh pihak asuransi kesehatan baik yang dikeluarkan oleh pemerintah maupun perusahaan. Pendapatan yang dimaksud adalah seluruh pendapatan (suami atau istri) dalam satu bulan termasuk gaji atau upah. Hasil pertanian, perdagangan dan lainnya diukur dalam satuan rupiah. Upah minimum provinsi sulsel tahun 2017 adalah Rp. 1.800.000,-.. (12)

Masyarakat kita pada pokoknya dapat dikelompokkan kedalam tiga golongan yaitu $^{(12)}$ :

a. Golongan atas

Yang termasuk golongan kedalam kelas ini antara lain: pengusaha-pengusaha kaya dan pejabat-pejabat tinggi.

b. Golongan menengah

Yang termasuk golongan kedalam kelas ini antara lain: karyawan instansi, pemerintah, pengusaha menengah.

c. Golongan rendah

Yang termasuk golongan kedalam ini antara lain: buruh-buruh pabrik, pegawai rendah, tukang becak, dan pedagang kecil.

\section{Faktor Mediko Obstetrik}

Hal-hal yang perlu diperhatikan pada faktor mediko obstetri adalah paritas, jarak persalinan, riwayat obstetri jelek, dimana hal ini akan memberi gambaran atau prognosa pada kehamilan dan persalinan berikutnya. ${ }^{(9)}$ 


\section{Paritas}

Paritas adalah jumlah persalinan yang pernah dialami oleh ibu sebelum kehamilan atau persalinan saat ini. Paritas dikategorikan menjadi 4 kelompok yaitu ${ }^{(13)}$ :

(1) Nullipara adalah ibu dengan paritas 0

(2) Primipara adalah ibu dengan paritas 1

(3) Multipara adalah ibu dengan paritas 2-5

(4) Grande Multipara adalah ibu dengan paritas $>5$

Persalinan yang pertama sekali biasanya mempunyai risiko yang relatif tinggi terhadap ibu dan anak, akan tetapi risiko ini akan menurun pada paritas kedua dan ketiga, dan akan meningkat lagi pada paritas keempat dan seterusnya. Paritas yang paling aman jika ditinjau dari sudut kematian maternal adalah paritas 2 dan 3. Risiko untuk terjadinya persalinan seksio sesarea pada primipara 2 kali lebih besar dari pada multipara.

\section{Jarak Persalinan}

Seorang wanita setelah melahirkan membutuhkan 2 sampai 3 tahun untuk memulihkan tubuhnya dan mempersiapkan dirinya pada persalinan berikutnya dan memberi kesempatan pada luka untuk sembuh dengan baik. Jarak persalinan yang pendek akan meningkatkan risiko terhadap ibu dan anak. ${ }^{(11,13)}$

\section{Riwayat Obstetri Buruk}

Daya tahan ibu pada saat hamil biasanya menurun sehingga penyakit yang pernah diderita sebelum hamil cenderung muncul pada saat hamil. Perlu diperhatikan karena penyakit tersebut dapat membahayakan keselamatanibudananakpadasaatpersalinan. Adapun penyakit-penyakit yang sering timbul kembali dan menyertai ibu hamil maupun bersalin adalah Hepatitis, TBC, Diabetes
Melitus, Penyakit Jantung, Asma Bronkial, Hipertensi, Penyakit infeksi, dan lainnya. Ibu dengan keadaan tersebut termasuk dalam kelompok ibu hamil risiko tinggi sehingga dapat mempengaruhi persalinannya. Riwayat hipertensi pada kehamilan mempunyai risiko 4 kali lebih besar terjadinya persalinan seksio sesarea dibandingkan dengan kehamilan tanpa hipertensi. ${ }^{(11)}$

Riwayat kehamilan yang berhubungan dengan risiko adalah pernah mengalami hiperemesis, perdarahan, abortus, preeklamsi dan eklamsi. Dengan memperoleh informasi tentang ibu secara lengkap pada masa lalu, diharapkan risiko kehamilan yang dapat memperberat keadaan ibu dan janin dapat diatasi dengan pengawasan obstetrik yang lebih baik. ${ }^{(11,12)}$

\section{Sistem Rujukan}

Sistem rujukan meneurut Sistem Kesehatan Nasional Depkes RI 2015, merupakan suatu system penyelenggaraan pelayanan kesehatan yang melaksanakan pelimpahan tanggung jawab timbal balikterhadap satu/lebih kasus penyakit atau masalah kesehatan yang secara vertical berasal dari unit berkemampuan kurang kepada unit yang lebih mampu atau secara horizontal antar unit-unit yang setingkat kemampuannya. ${ }^{(13)}$

Sistem Rujukan pelayanan kesehatan adalah penyelenggaraan pelayanan kesehatan yang mengatur pelimpahan tugas dan tanggung jawab pelayanan kesehatan secara timbal balik baik vertikal maupun horizontal yang wajib dilaksanakan oleh peserta jaminan kesehatan atau asuransi kesehatan sosial, dan seluruh fasilitas kesehatan. Pelayanan kesehatan perorangan terdiri dari 3 (tiga) 
tingkatan yaitu:

a. Pelayanan kesehatan tingkat pertama;

b. Pelayanan kesehatan tingkat kedua; dan

c. Pelayanan kesehatan tingkatketiga.

Pelayanan kesehatan tingkat pertama merupakan pelayanan kesehatan dasar yang diberikan oleh fasilitas kesehatan tingkat pertama. Pelayanan kesehatan tingkat kedua merupakan pelayanan kesehatan spesialistik yang dilakukan oleh dokter spesialis atau dokter gigi spesialis yang menggunakan pengetahuan dan teknologi kesehatan spesialistik.

Pelayanan kesehatan tingkat ketiga merupakan pelayanan kesehatan sub spesialistik yang dilakukan oleh dokter sub spesialis atau dokter gigi sub spesialis yang menggunakan pengetahuan dan teknologi kesehatan subspesialistik.

Dalam menjalankan pelayanan kesehatan, fasilitaskesehatan tingkatpertama dan tingkat lanjutan wajib melakukan sistem rujukan dengan mengacu pada peraturan perundang- undangan yang berlaku. Peserta yang ingin mendapatkan pelayanan yang tidak sesuai dengan sistem rujukan dapat dimasukkan dalam kategori pelayanan yang tidak sesuai dengan prosedur sehingga tidak dapatdibayarkan oleh BPJS Kesehatan.

Fasilitas Kesehatan yang tidak menerapkan sistem rujukan maka BPJS Kesehatan akan melakukan recredentialing terhadap kinerja fasilitas kesehatan tersebut dan dapat berdampak pada kelanjutan kerjasama. Pelayanan rujukan dapat dilakukan secara horizontal maupun vertikal.

Rujukan horizontal adalah rujukan yang dilakukan antar pelayanan kesehatan dalam satu tingkatan apabila perujuk tidak dapat memberikan pelayanan kesehatan sesuai dengan kebutuhan pasien karena keterbatasan fasilitas, peralatan dan/atau ketenagaan yang sifatnya sementara atau menetap.

Rujukan vertikal adalah rujukan yang dilakukan antar pelayanan kesehatan yang berbeda tingkatan, dapat dilakukan dari tingkatpelayanan yang lebih rendah ketingkat pelayanan yang lebih tinggi atau sebaliknya. Rujukan vertikal dari tingkatan pelayanan yang lebih rendah ke tingkatan pelayanan yang lebih tinggi dilakukan apabila:

a. pasien membutuhkan pelayanan kesehatan spesialistik atau subspesialistik;

b. perujuk tidak dapat memberikan pelayanan kesehatan sesuai dengan kebutuhan pasien karena keterbatasan fasilitas, peralatandan/atauketenagaan.

c. Rujukan vertikal dari tingkatan pelayanan yang lebih tinggi ke tingkatan pelayanan yang lebih rendah dilakukan apabila:

a. permasalahan kesehatan pasien dapat ditangani oleh tingkatan pelayanan kesehatan yang lebih rendah sesuai dengan kompetensi dan kewenangannya;

b. kompetensi dan kewenangan pelayanan tingkat pertama atau kedua lebih baik dalam menangani pasien tersebut;

c. pasien membutuhkan pelayanan lanjutan yang dapat ditangani oleh tingkatan pelayanan kesehatan yang lebih rendah dan untuk alasan kemudahan, efisiensi dan pelayanan jangka panjang; dan/atau 
d. perujuk tidak dapat memberikan pelayanan kesehatan sesuai dengan kebutuhan pasien karena keterbatasan sarana, prasarana, peralatan dan/atau ketenagaan.

Sistem rujukan pelayanan kesehatan dilaksanakan secara berjenjang sesuai kebutuhan medis, yaitu:

a. Dimulai dari pelayanan kesehatan tingkat pertama oleh fasilitas kesehatan tingkat pertama.

b. Jika diperlukan pelayanan lanjutan oleh spesialis, maka pasien dapat dirujuk ke fasilitas kesehatan tingkatkedua.

c. Pelayanan kesehatan tingkat kedua di faskes sekunder hanya dapat diberikan atas rujukan dari faskes primer.

d. Pelayanan kesehatan tingkat ketiga di faskes tersier hanya dapat diberikan atas rujukan dari faskes sekunder dan faskes primer.

Pelayanan kesehatan di faskes primer yang dapat dirujuk langsung ke faskes tersier hanya untuk kasus yang sudah ditegakkan diagnosis dan rencana terapinya, merupakan pelayanan berulang dan hanya tersedia di faskes tersier. Ketentuan pelayanan rujukan berjenjang dapat dikecualikan dalam kondisi:

a. Terjadi keadaan gawat darurat; Kondisi kegawatdaruratan mengikuti ketentuan yang berlaku.

b. Bencana; Kriteria bencana ditetapkan oleh Pemerintah Pusat dan atau Pemerintah Daerah.

c. Kekhususan permasalahan kesehatan pasien; untuk kasus yang sudah ditegakkan rencana terapinya dan terapi tersebut hanya dapat dilakukan difasilitas kesehatan lanjutan. d. pertimbangan geografis; dan

e. pertimbangan ketersediaan fasilitas. Pelayanan oleh bidan dan perawat

a. Dalam keadaan tertentu, bidan atau perawat dapat memberikan pelayanan kesehatan tingkat pertama sesuai ketentuan peraturan perundangundangan.

b. Bidan dan perawat hanya dapat melakukan rujukan ke dokter dan/ atau dokter gigi pemberi pelayanan kesehatantingkatpertama kecualidalam kondisi gawat darurat dan kekhususan permasalahan kesehatan pasien, yaitu kondisi di luar kompetensi dokter dan/ atau dokter gigi pemberipelayanan kesehatan tingkat pertama

Rujukan Parsial adalah pengiriman pasien atau spesimen ke pemberi pelayanan kesehatan lain dalam rangka menegakkan diagnosis atau pemberian terapi, yang merupakan satu rangkaian perawatan pasien di Faskes tersebut. Rujukan parsial dapat berupa:

a. Pengiriman pasien untuk dilakukan pemeriksaan penunjang atau tindakan

b. Pengiriman spesimen untuk pemeriksaan penunjang

c. Apabila pasien tersebut adalah pasien rujukan parsial, maka penjaminan pasien dilakukan oleh fasilitas kesehatan perujuk.

Angka Kematian Ibu (AKI) di Sulawesi Selatan semakin meningkat sejak tahun 2013. Pada tahun 2015, AKI di Sulawesi Selatan tercatat 149/100.000. Angka kematian ibu di Indonesia tahun 2012 sebanyak 359 per 100.000 kelahiran hidup, tetap tinggi di dalam tahun-tahun terakhir, meskipun telah 
dilakukan upaya-upaya untuk meningkatkan pelayanan kesehatanibu. Sedangkan menurut MDG's 2015 angka kematian ibu diharapkan 102/100.000 kelahiran hidup. Angka kematian perinatal 32/1000 kelahiran hidup, sementara target angka kematian bayi yang diharapkan 23/1000 kelahiran hidup(14).

Salah satu penyebab lambatnya penurunan AKI karena masih banyaknya terjadi kasus rujukan terlambat. Faktor lain penyumbang AKI adalah kegawatan obstetrik. Kegawatan obstetrik adalah kondisi kesehatan yang mengancam jiwa yang terjadi dalam kehamilan atau selama dan sesudah persalinan dan kelahiran. Di dalam bidang obstetrik ada dua pasien yang mendapat perhatian utama yaitu ibu dan bayi atau fetus. Penanganan terhadap pasien tersebut akan mempengaruhi satu sama lain. Kadangkala penanganan berdampak baik untuk salah satunya dan berdampak buruk untuk yang lainnya. Kegawatandaruratan dalam bidang obstetrik yang paling sering ditemui antara lain adalah persalinan premature, eklampsia, preeclampsia, proplapsus tali pusat, perdarahan antepartum, aborsi dengan syok perdarahan, nyeri akut pada kehamilan, DIC (Disseminated Intravaskular Coagulation), Perdarahan Post Partum, Distosia Bahu, Emboli Cairan Amnion, Inversi Uteri, dan Trauma padakehamilan. ${ }^{(14,15)}$

Sitem rujukan dalam bidang obstetrik pada dasarnya mempunyai maksud dan tujuan untuk memberikan pelayanan yang sesuai dengan yang diperlukan ibu hamil khususnya yang perlu dirujuk untuk mendapatkan perawatan spesialistik, sehingga diharapkan dapat dicapai tingkat kesehatan ibu hamil, bersalin, dan nifas yang optimal. Dengan adanya system rujukan yang baik diharapkan kasus-kasus dengan resiko tinggi dapat ditangani dengan lebih cepat, tepat dan berkesinambungan, yang pada akhirnya kematian ibu dan anak sebagai tolak ukur pelayanan kesehatan reproduksi dapat diturunkan ${ }^{(13,16)}$.

Tingkat kedaruratan proses seleksi triase pasien dalam menentukan prioritas penanganan dikarenakan terbatasnya tenaga dan sarana/prasarana kesehatan dirumah sakit. Dibagi menjadi ada potensi gawat obstetri (APGO), ada gawat obstetrik (AGO), ada gawatdarurat obstetrik(AGDO) ${ }^{(16)}$.

Dalam Rujukan Kesehatan, adabeberapa aspekyang harus diperhatikan yaitu ${ }^{(13)}$ :

a. Klasifikasi Fasilitas Kesehatan

b. Lokasi/Wilayah/Kabupaten/Kota

c. Koordinasi unsur-unsur pelaksana teknis

Kendala dalam pelaksanaan rujukan mempengaruhi kematian maternal. Ada tiga "terlambat" yang mempengaruhi kematian maternal/perinatal adalah; terlambat mengenali bahaya dan mengambil keputusan merujuk, terlambat mencapai fasilitas pelayanan rujukan danterlambat memperoleh pelayanan adekuatdifasilitas rujukan.

\section{Komplikasi Medis}

Komplikasi obstetri sangat berpengaruh berpengaruh terhadap kematian maternal. Masalah kematian maternal merupakan masalah yang kompleks karena menyangkut banyak hal, yakni derajat kesehatan termasuk status kesehatan reproduksi sebelum dan selama kesehatan. Kejadian komplikasi obstetrik terdapat pada sekitar $20 \%$ dari seluruh ibu hamil, namun kasus komplikasi obstetrik yang tertangani masih kurang dari $10 \%$ dari semuaibu hamil. Targetpenanganan 
kasus komplikasi obstetrik yang ditetapkan adalah minimal $12 \%$ dari semua ibu hamil (atau $60 \%$ dari total kasus komplikasi obstetrik). Contoh komplikasi medis: ${ }^{17,18)}$

1. Kehamilan Dengan Perdarahan

Perdarahan antepartum atau perdarahan pada kehamilan lanjut adalahperdarahan pada trimester dalam kehamilan sampai bayi dilahirkan. Pada kehamilanlanjut, perdarahan yang tidak normal adalah merah, banyak dantidak selalu, disertai dengan rasa nyeri.

2. Kehamilan Dengan Pre eklampsi dan Eklampsi.

Preklampsi dan eklampsi merupakan penyakit yang berkelanjutan dengan batas atau tambahan kejang atau koma. Gejala pre eklamsi yaitu pandangan mata kabur, sakit kepala yang berat dan menetap, nyeri ulu hati, bengkak pada muka dan tangan. Bahayanya bagi ibu adalah kejang dan kematian sedangkan bagijanin adalah gawatjanin dan kematian. Eklampsi merupakan kelanjutan dari pre eklampsi berat yang disertai kejang atau koma.

\section{DAFTAR PUSTAKA}

1. Djamhoer dkk. 2011. Bunga Rampai Obstetri dan Ginekologi Sosial, PT Bina Pustaka Sarwono Prawirohardjo.

2. Kementerian Kesehatan RI. 2015. Sekretariat Jenderal. Rencana Strategis Kementerian Kesehatan tahun 20152019. Jakarta: Kementerian Kesehatan RI.

3. Dewi, Y dan H. Fauzi. 2007. Operasi Caesar pengantar Dari A sampai Z. Jakarata Edsa Mahkota.
4. Republik Indonesia. 2004. UndangUndang Republik Indonesia No. 40 Tahun 2004 tentang Sistem Jaminan Sosial Nasional. Jakarta.

5. Evans, D. B., Hsu, J., \& Boerma, T. 2013. (UHC) Universal Health Coverage \& Universal Access, Vol. 91: 8(2013). Pro Quest, 546.546A.

6. Notoadmojo, Soekidjo. 2007. Kesehatan Masyarakat Ilmu dan Seni. Jakarta Rineka Cipta.

7. Republik Indonesia. 2009. UndangUndang Nomor. 44 Tahun 2009 tentang Rumah Sakit.Jakarta.

8. Salfariani, Intan2012. Faktor-faktoryang mempengaruhi ibu memilih persalinan Sectio Caesarea tanpa indikasi Medis di Rumah sakit Umum Bunda Tamrin Medan. [Skripsi] Fakultas Kesehatan Masyarakat Universitas Sumatera Utara Vol 1 No 12012.

9. Sumarwan, Ujang. 2014. Perilaku Konsumen: Teori dan penerapannya dalam pemasaran. Bogor, Gjalia Indonesia.

10. Margaretha, I, G. 2003. Analisis faktorfaktor yang berhubungan dengan keputusan Dalam memilih layanan ruang rawat inap kelas 1 , VIP dan VVIP di Rumah sakit Bhakti Yudha: Depok. FKM UI.

11. Hutabalian, Dintar. 2011. Pengaruh Faktor Internal dan Eksternal Ibu bersalin terhadap indikasi tindakan Sectio Caesarea Dalam Persalinan Di Rumah Sakit Umum Daerah Swadana Taratung. Program S2 Fakultas Kesehatan MasyarakatUSU. Medan.

12. Survei Demografi dan Kesehatan Indonesia. 2008. 
13. Kementerian Kesehatan Republik Indonesia. 2015. Pedoman Sistem Rujukan Nasional. Jakarta: Direktorat Jenderal BUK (Bina Upaya Kesehatan) Kementerian Kesehatan Republik Indonesia .

14. Kasdu, Dini. 2003. Operasi Caesarea Masalah dan Solusinya. Jakarta: Puspa Swara.

15. Wiknjosastro S., 2005. Ilmu kebidanan Edisi Ketiga. Jakarta: Yayasan Bina Pustaka Sarwono Prawiroharjo.

16. Bobak, Lowdermilk, Jensen. 2004. Keperawatan Maternal. Jakarta: EGC.

17. Budianti, Windi. 2011. Faktor faktor yang berhubungan dengan persalinan Sectio Caesarea di Wilayah Puskesmas WIRE kecamatan Semanding Kabupaten Tuban, [Skripsi] Fakultas Kesehatan Masyarakat Indonesian Rekam Medik Rumah Sakit Ibu dan Anak Sitti Khadijah I, Makassar.

18. Cunningham B, Hauth, Spong. 2010. Fisiologi ibu hamil. Obstetri Williams. 1: EGC Medical; p. 118-9.

19. Silvia, Aulia. 2011. Faktor-faktor risiko persalinan Sectio Caesarea di RSUD Dr. Adijidarmo Lebak. Fakultas kedokteran ilmu kesehatan universitas Islam Negeri Syarif Hidayatullah Jakarta Setiadi. Konsep dan Keperawatan keluarga, Surabaya: Graha Ilmu.

20. Anderson, L. W, Krathwolh. D. R. 2011. A Taxonomy For Learning, Teaching and Assesing: A Revision of Bloom's Taxonomy of Education. New York; Edition Wesley Lonman inc.
21. Mulyawati, Isti, dkk. 2011. Faktor tindakan persalinan Operasi Sectio Caesarea. Jurnal kesehatan Masyarakat Universitas Negeri Semarang Vol.7 No. 1.

22. Nurak, Maria Trivonia. 2011. Indikasi Persalinan Sectio Caesarea Berdasarkan Ummur dan Paritas Di Rumah Sakit SKT Gubeng Pojok Surabaya, Karya Tulis Ilmiah USU.

23. Suryani. 2008. Hubungan karakteristik ibu bersalin dan Antenatal Care dengan perdarahan pasca persalinan di rumah sakit umum dr. Pringadi Medan. Jurnal ilmiah Pannmed, Vol. 3.

24. Setiadi. 2008. Konsep dan Keperawatan keluarga, Surabaya: Graha Ilmu. 
